\begin{tabular}{|c|c|c|}
\hline \hline & $\begin{array}{c}\text { International Journal of Current Research in } \\
\text { Biosciences and Plant Biology }\end{array}$ \\
\hline EXCELLENT \\
PUBLISHERS
\end{tabular}

\title{
In Vitro Radiosensitivity for Two Genotypes of Potato (Solanum tuberosum L.) and Physiological Studies under Salinity
}

\author{
Z. A. AL-Hussaini ${ }^{1}$, SH. A. Yousif ${ }^{1}$ and S. A. AL-Ajeely ${ }^{2}$ \\ ${ }^{I}$ Ministry of Science and Technology, P.O. Box 765, Baghdad, Iraq \\ ${ }^{2}$ Faculty of Girl Education, Kufa University, Iraq \\ *Corresponding author; Part of Ph.D. Thesis of the first author.
}

\begin{tabular}{|c|c|}
\hline Abstract & Article Info \\
\hline \multirow{6}{*}{$\begin{array}{l}\text { In order to determine the optimal radiation dose, the sensitivity of Riviera and Burren } \\
\text { genotypes to gamma rays was tested. Cuttings exposed to gamma irradiation of } 0,5,10 \text {, } \\
15,20,25 \text { and } 30 \mathrm{~Gy} \text { and placed in callus induction medium, which showed that } 0,5,10 \\
\text { and } 15 \mathrm{~Gy} \text { were gave higher percentage reached } 100 \% \text { with shorter times }(10-12 \text { days) for } \\
\text { each genotypes while } 20 \text { and } 25 \mathrm{~Gy} \text { caused reduction in callus induction and increasing } \\
\text { the time taken for induction. Results based on callus growth criteria showed the optimal } \\
\text { doses for mutation were } 12 \text { and } 18 \mathrm{~Gy} \text { for Burren and Riviera respectively. Irradiated and } \\
\text { non irradiated calli were planted in medium supplemented with different salt levels }(6,8 \text {, } \\
\left.10,12 \mathrm{dS} \mathrm{m}^{-1}\right) \text {. At all salt levels, radiation decreased callus fresh weight, relative growth } \\
\text { rate and water content and increased accumulation of } \mathrm{K}^{+}, \mathrm{Na}^{+}, \mathrm{Cl}^{-} \text {and proline. Ca }{ }^{++} \text {and } \\
\text { carbohydrate accumulations was not affected by radiation. In both genotypes, } \\
\text { salinity stress decreased callus fresh weight, relative growth rate and water content and }\end{array}$} & $\begin{array}{l}\text { Accepted: } 16 \text { August } 2017 \\
\text { Available Online: } 06 \text { September } 2017\end{array}$ \\
\hline & Keywords \\
\hline & Callus \\
\hline & Potato \\
\hline & Radiation sensitivity \\
\hline & Salinity \\
\hline
\end{tabular}

\section{Introduction}

Radiosensitivity has been defined as a measure of cells susceptibility when exposed to radiation. Biological effects of Radiation are determined by directed and in direct, The first one caused damage in genetic material (DNA) especially if absorbed energy was enough to root out electrons from DNA molecule leading to break occurs for one or both of strands causing a change in the genetic code or leading to cell death. While the second, caused decomposition of water and be free radicals (Kovac and Keresztes, 2002).

Radiosensitivity test is a necessary priorities in plant breeding program by induction and mutant breeding (FAO/IAEA, 1977; Ibrahim et al., 1990; Van Hartin, 1998). On this side, many studies mentioned to these sensitivity for many varieties of Potato growing in vitro (Sonnino et al., 1986; Hassan and Javed, 1991; ALsalhi, 2002). Salinity is a serious problem, affect plant growth and productivity in many crop. Many parameters can be used to determine tolerance to salinity stress such as fresh and dry weight, ion, proline and carbohydrates accumulation. Potato has been classified as a moderately salt sensitive with thresholds $1.7 \mathrm{dS} \mathrm{m}^{-1}$ (Maas and Hoffman, 1977).

Yaycili and Alikamanoglu, 2012 studied many 
parameters (percentage of regeneration, plant height, number of leaves and the percentage of roots formation) after exposed stem cuttings of Marfona cultivar to different doses of Gamma rays, They found that 18 Gy caused reduction $30 \%$ in all parameters except plant height, while 26, 23 and 20 Gy caused reduction 50\% in percentage of regeneration and number of leaves, root formation and plant height, respectively. Also ALSafadi et al. (2000) found that 2.5 Gy caused an increase number of microtuber (38\%) while the weight of microtuber was not affected and they concluded that this dose possible use in promoting microtuber formation without caused variation.

The objective of this study is expand of genetic variation by using radiation (Gamma rays) and determining the optimal dose which caused reduction $50 \%$ in fresh weight and using physiological markers as an indicator to salt tolerance for two genotypes of Potato (Riviera and Burren).

\section{Materials and methods}

The research was conducted at Genetic Engineering Department in Agricultural Research Directorate in Ministry of Science and Technology/Iraq. Potato varieties (Riviera and Burren) were micropropagated on MS (Murashige and Skoog, 1962) nutrient medium; $\mathrm{pH}$ was adjusted to 5.7 prior to autoclaving at $121^{\circ} \mathrm{C}$ for 20 minutes.

\section{In vitro radiosensitivity}

For radiosensitivity, Potato plantlets of Riviera and Burren were exposing with different doses $(5,10,15$, 20 and $25 \mathrm{~Gy}$ ) of Gamma rays (source Co ${ }^{60}$ with activity $243 \mathrm{~Gy}$ hour $\left.^{-1}\right)$. intermodal segments $(1-1.5 \mathrm{~cm})$ were excised and placed on Petri dishes containing callus induction medium MS with 3\% sucrose, $8 \%$ agar and $0.1,100,0.5,0.5,2,2 \mathrm{mg} \mathrm{L}^{-1}$ of Thiamine -HCL, Inositol, Glycin, Nicotinic Acid, BA and 2,4-D respectively. The cultures were incubated in growth room chamber at $25^{\circ} \mathrm{C} \pm 2$ under $16 \mathrm{~h}$ light and $8 \mathrm{~h}$ dark. Data of \% callus induction, number of days required for callus induction, callus morphology, callus fresh weight (mg) were taken. The optimal dose was calculated as $50 \%$ reduction in fresh weight of callus as follows:

$\%$ Reduction $=(\{$ Callus fresh weight in control treatment - Callus fresh weight in irradiated treatment $\}$ / Callus fresh weight in control treatment) $\times 100$

\section{In vitro salt tolerance}

After determined the optimal dose, 12 and 18 Gry for Burren and Riviera genotypes respectively, stem segments (approximately $1-1.5 \mathrm{~cm}$ size, without node) were excised from irradiated and non irradiated in vitro plantlets and planted in the previous medium supplemented with different levels of $\mathrm{NaCl}$ to generate $\mathrm{EC}$ at $8,10,12 \mathrm{dSm}^{-1}$, the EC of the control treatment (MS basal medium, without adding $\mathrm{NaCl}$ ) was $6 \mathrm{dSm}^{-1}$. All cultures were placed in a growth room chamber under the same light and environmental conditions as previously stated. After 30 days several characteristics were recorded. These include:

Callus fresh weight (mg): callus was divided into pieces of $150 \mathrm{mg}$ (initial fresh weight), 5 pieces were placed in Petri dishes containing MS medium supplemented with different levels of EC $\left(6,8,10\right.$ and $\left.12 \mathrm{dSm}^{-1}\right)$ after one month final callus fresh weight were recorded.

Relative Growth Rate (RGR) was calculated following the formulae of Lutts et al. (1998): RGR (mg x $10^{-2} \mathrm{gm}^{-1}$ callus fresh weight/day) $=\ln \mathrm{W} 2 \ln \mathrm{W} 1 / \Delta \mathrm{t}$ Where $\mathrm{W} 1$ refers to initial fresh weight. W2 refers to final fresh weight. $\Delta t$ refers to the time for culturing (30 day).

Water content estimated according to Forooghian and Esfarayeni (2013) Relative Water Content of callus = [(Wet weight of callus - Dry weight of callus) /Wet weight of callus] $\times 100$ Callus dry weight was determined after 2 days oven dried at $60^{\circ} \mathrm{C}$.

Determination of ions content: $150 \mathrm{mg}$ dry weight callus was placed in beaker containing $9 \mathrm{ml}$ digesting mixture (10 Nitric acid: 4 Perchloric acids: 1 sulfuric acid). The beakers were heated up to $60{ }^{\circ} \mathrm{C}$ until the solution became colorless then the digestion diluted with distilled water. Concentrations of $\mathrm{Ca}++, \mathrm{Na}+$ and $\mathrm{K}+$ were measured using Atomic Absorption Spectrophotometer (Shimadzo AA-670) according to the manufacturer's recommendation, While $\mathrm{Cl}^{-}$estimated by digesting with $37.5 \mathrm{mg}$ Cao and $90 \mathrm{ml}$ distilled water in ceramic container. The container placed on sand path until the solution evaporation then transferred to furnace oven at $550^{\circ} \mathrm{C}$ for $2 \mathrm{hrs}$. Sample was cool and added hot distilled water and filtered. completed volume $(100 \mathrm{ml})$ with 5 drops of potassium chromate $(1 \%) .10 \mathrm{ml}$ from solution placed on beaker and flow with $\mathrm{Ag} \mathrm{No}_{3}(0.05$ N) until the solution became pink. Concentration of $\mathrm{Cl}^{-}$ was measured using following the equation: 
$\mathrm{Mg}^{-1} \mathrm{Cl}$ callus dry weight $=\left[\mathrm{Ag} \mathrm{No}_{3}(\mathrm{ml}) \times \mathrm{Ag} \mathrm{No}_{3}(\mathrm{~N}) /\right.$ Sample volume] / dilution factor.

Determination of carbohydrate content: $200 \mathrm{mg}$ fresh weight callus was placed in test tube containing $1 \mathrm{ml}$ distilled water then digested and centrifuged at 1500 $\mathrm{rpm} \mathrm{min}^{-1}$ for 10 minute. 20 micro liter from phenol indicator (5\% weight /volume) was added to 300 micro liter of the sample then adding 150 micro liter $\mathrm{H}_{2} \mathrm{So}_{4}$. Sample was incubated in path water at $25-35^{\circ} \mathrm{C}$ for 20 min. colored intensity was determined by measured optical density using microplate reader spectrophotometer at wavelength 488 nanometer. Concentrations of carbohydrate was measured as follow as: $\mathrm{mg}$ glucose $\mathrm{gm}^{-1}$ callus fresh weight $=$ (reading device / dilution factor) $\times$ the volume of reading.

Determination of proline content: $30 \mathrm{mg}$ dry weight callus was taken and mixed with 800 micro liter sulpha salicylic acid (3\%) then digested and centrifuged at 2000 $\mathrm{rpm} \mathrm{min}^{-1}$ for 10 minute. $0.5 \mathrm{ml}$ from acetic acid and $0.5 \mathrm{ml}$ ninhydrin solution adding to mixture solution $(0.5 \mathrm{ml})$ then incubated in path water for $30 \mathrm{~min}$. Red layer isolated by adding $2 \mathrm{ml}$ toluene then colored intensity was determined by measured optical density using microplate reader spectrophotometer at wavelength 520 nanometer. Concentrations of proline was measured as follow as:

Micromole proline $\mathrm{gm}^{-1}$ callus dry weight $=[($ microgram proline/ml $\times \mathrm{ml}$ toluene)/115.5/ micro mol) / dilution factor).
Results were statistically analyzed using GenStat program and means were separated using Duncan's test at a probability level of $5 \%$.

\section{Results and discussion}

\section{In vitro radiosensitivity}

Results in Table 1 revealed that in both cultivars, \% callus induction significantly increased with increasing radiation doses at $0,5,10$ and 15 Gy with days required for callus induction ranged 10-12 days. While the doses 20 and 25 Gy caused significantly decreased in callus induction (52.0 and 44.0\% , 68.0 and 64.0\% for Riviera and Burren respectively), with increasing number of days required for callus induction ranged 12-14 days. The results in Table 2 showed that callus fresh weight significantly decreased with increasing irradiation doses in both genotypes. Callus growth was different among genotypes in the control treatment (non irradiated) and irradiated at 5 Gy, the highest callus fresh weight was recorded in Burren (548.00 and $566.42 \mathrm{mg}$ ) respectively. Callus color in the control treatment ranged from green - compact (Burren) to greenish compact with white aria, while the color at 15 , 20 and 25 Gy ranged from green - compact with brown to greenish brown compact for both genotypes (Table 2; Figs. 1 and 2). Decreased in all callus characterize with increasing radiation doses may be due to decrease in internal growth regulators, especially cytokines, as a result of their fragmentation or lack of manufacturing (Omar et al., 1993).

Table 1. Effect of gamma doses on \% callus induction, number of days required for callus induction, fresh weight and callus morphology of potato genotypes.

\begin{tabular}{|c|c|c|c|c|c|c|c|c|}
\hline \multirow[t]{2}{*}{$\begin{array}{l}\text { Gamma } \\
\text { doses Gy }\end{array}$} & \multicolumn{2}{|c|}{$\%$ callus induction } & \multicolumn{2}{|c|}{$\begin{array}{l}\text { Number of days } \\
\text { required for callus } \\
\text { induction }\end{array}$} & \multicolumn{2}{|c|}{ Fresh weight ( mg) } & \multicolumn{2}{|c|}{ Callus morphology ( color-texture) } \\
\hline & Riviera & Burren & Riviera & Burren & Riviera & Burren & Riviera & Burren \\
\hline 0 & $100 \mathrm{a}$ & $100 \mathrm{a}$ & $10.00 \mathrm{e}$ & $10.80 \mathrm{~d}$ & $404.00 \mathrm{~b}$ & $548.00 \mathrm{a}$ & $\begin{array}{l}\text { greenish compact } \\
\text { with white area }\end{array}$ & green - compact \\
\hline 5 & $100 \mathrm{a}$ & $100 \mathrm{a}$ & $11.00 \mathrm{~d}$ & $11.00 \mathrm{~d}$ & $398.92 b$ & $566.42 \mathrm{a}$ & greenish & $\begin{array}{l}\text { greenish with purple } \\
\text { area, compact }\end{array}$ \\
\hline 10 & $100 \mathrm{a}$ & $100 \mathrm{a}$ & $11.00 \mathrm{~d}$ & $11.00 \mathrm{~d}$ & $289.04 \mathrm{bcd}$ & $295.72 b c$ & $\begin{array}{l}\text { green- compact } \\
\text { with roots }\end{array}$ & $\begin{array}{l}\text { Compact - with green } \\
\text { area and purple area }\end{array}$ \\
\hline 15 & $100 \mathrm{a}$ & $100 \mathrm{a}$ & $12.00 \mathrm{c}$ & $12.00 \mathrm{c}$ & $250.00 \mathrm{~cd}$ & $252.00 \mathrm{~cd}$ & $\begin{array}{l}\text { green- compact } \\
\text { with brown }\end{array}$ & $\begin{array}{l}\text { Compact }- \text { with green } \\
\text { area and purple area }\end{array}$ \\
\hline 20 & $52.0 \mathrm{~b}$ & $44.0 \mathrm{~b}$ & $12.70 b$ & $12.80 \mathrm{~b}$ & $172.00 \mathrm{cde}$ & $54.00 \mathrm{e}$ & $\begin{array}{l}\text { green- compact } \\
\text { with brown }\end{array}$ & $\begin{array}{l}\text { Compact - with green } \\
\text { area and brown area }\end{array}$ \\
\hline 25 & $68.0 \mathrm{~b}$ & $64.0 \mathrm{~b}$ & $13.90 \mathrm{a}$ & $14.00 \mathrm{a}$ & 144.00de & $68.00 \mathrm{e}$ & $\begin{array}{l}\text { green- compact } \\
\text { with brown }\end{array}$ & $\begin{array}{l}\text { greenish brown } \\
\text { compact }\end{array}$ \\
\hline
\end{tabular}

The average which have the same letter not significant difference according to Duncan polynomial test at 5\% level. 


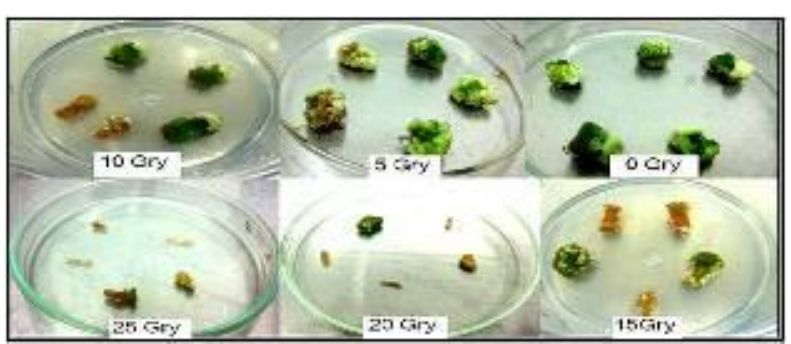

Fig. 1: effect of gamma rays on callus phenotypes for Burren genotype.

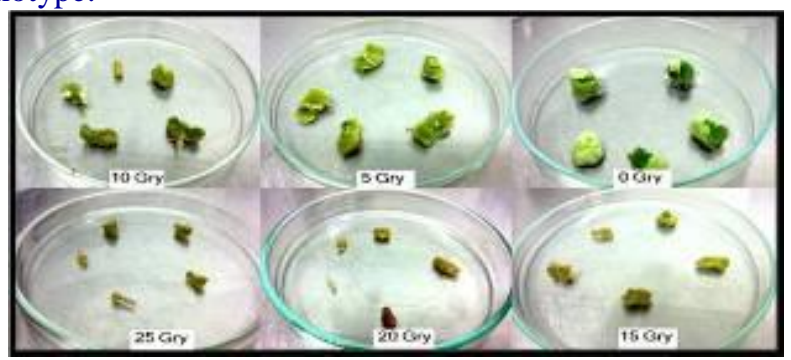

Fig. 2: Effect of gamma rays on callus phenotypes for Riviera genotype.

\section{Determination of the optimal dose}

Results in Fig. 3 showed that the percentage of reduction in fresh weight of callus which induced from Riviera and Burren genotypes increased with increasing irradiation doses. The optimal dose, which gave 50\% reduction in the fresh weight, was 12 and $18 \mathrm{~Gy}$ for Burren and Riviera respectively. By dotting points, and these two doses were adopted to cause variations in subsequent experiments. The reduction in growth of 30 $50 \%$ is a criterion for the optimal dose at which a sufficient quantity of plants grows later and produces viable seeds that produce mutant plants that are non sterile (AL-Takretti, 2002; van Harten, 1998).

\section{Effect of salinity and irradiation on physiological indicators}

Results in the Table 2 showed that in non irradiation treatment significant superiority of the fresh weight of Riviera genotype compared with the Burren genotype in all salt levels (1542.6, 2098, 1028.3 and $1348.1 \mathrm{mg}$ at 6, 8,10 and $12 \mathrm{dS} \mathrm{m}^{-1}$ Respectively), while in irradiation treatment there was no significant difference in both genotypes.

As for the Relative Growth Rate (RGW), irradiation has a significant effect on the growth of Burren genotype at salt levels 8 and $10 \mathrm{dS} \mathrm{m}^{-1}$ (1.84 and $1.63 \mathrm{gm} \mathrm{gm}^{-1}$ callus fresh weight $\times 10^{-2}$ respectively), while it not significantly affect on Riviera genotype under all salt levels compared with non irradiation treatment (Table 2).

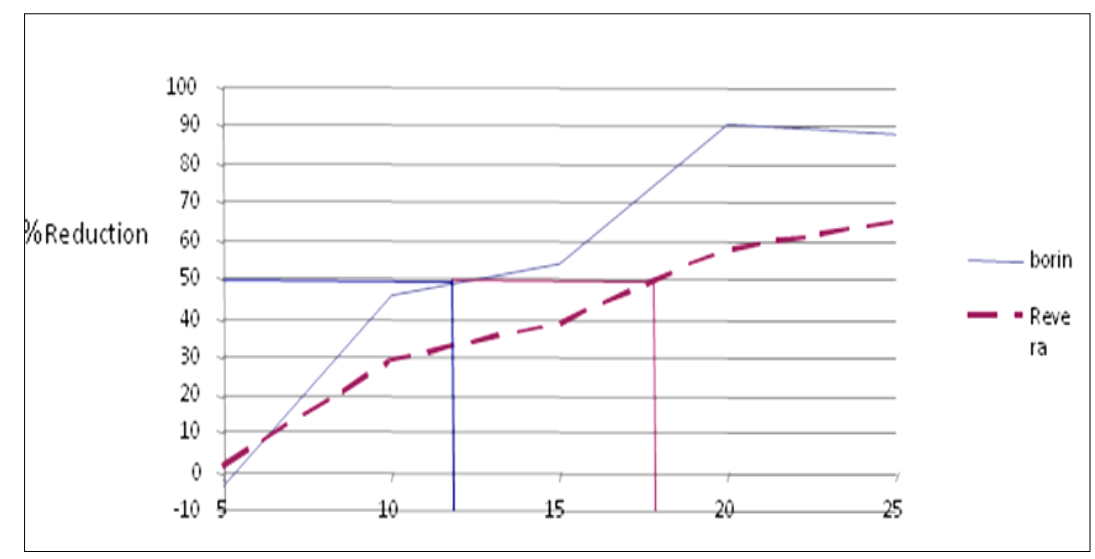

Fig. 3: Effect of different doses of Gamma rays on callus fresh weight for Riviera and Burren genotypes.

The result for Relative Water Content of callus is given in Fig. 2 showed that irradiation caused significant decrease in the Relative Water Content at $12 \mathrm{dS} \mathrm{m}^{-1}$ in Riviera tissue ( 88.09 ) compared with other levels, while non irradiated treatment caused the same effect at $12 \mathrm{dS} \mathrm{m}^{-1}$ for both Riviera and Burren genotypes (83.80 and 85.60). It is clear from the results that salinity has caused reduction in fresh weight, Relative growth Rate and Relative water content may be related to the tissue through the total energy availability of stress metabolic processes, which delays callus growth (Cushman et al., 1990), or readiness of water and soluble nutrients in the salt medium, which is reflected on cell division and growth.

Also Queiros et al. (2007) explained the reduction in the water content may be due to the high osmotic pressure of the culture medium with high salt concentration. The inhibitory effect of irradiation, either as a single factor or in combination with different salinity levels, has been 
noted by several studies (Aldemita and Zapata, 1991; ALTikriti, 2002) due to increased radiation damage at the level of chromosomes in the merismatic cells and delay the division process (Yaycili and Alikamanoglu, 2012).

Table 2. Effect of radiation and salt levels on Fresh weight, Relative growth rate and Relative water content for two genotypes (Riviera and Burren) after 30 days.

\begin{tabular}{|c|c|c|c|c|c|}
\hline \multirow{2}{*}{ Radiation } & \multirow{2}{*}{ Genotypes } & \multicolumn{4}{|c|}{ Salt levels dS $\mathrm{m}^{-1}$} \\
\hline & & 6 & 8 & 10 & 12 \\
\hline \multicolumn{6}{|c|}{ Fresh weight (mg) } \\
\hline \multirow[t]{2}{*}{ Non-irradiation } & Riviera & 2098.6a & $1542.6 \mathrm{~b}$ & $1348.1 b c$ & $1028.3 \mathrm{~cd}$ \\
\hline & Burren & $506.3 \mathrm{e}$ & $475.1 \mathrm{e}$ & $442.1 \mathrm{e}$ & $266.3 \mathrm{e}$ \\
\hline \multirow[t]{2}{*}{ Irradiation } & Riviera & $748.73 \mathrm{de}$ & $520.87 \mathrm{e}$ & $397.30 \mathrm{e}$ & $317.83 \mathrm{e}$ \\
\hline & Burren & $414.97 \mathrm{e}$ & $345.4 \mathrm{e}$ & $306.43 \mathrm{e}$ & $280.67 \mathrm{e}$ \\
\hline \multicolumn{6}{|c|}{ Relative growth rate ( $\mathrm{gm} \mathrm{gm}^{-1}$ callus fresh weight $\times 10^{-2}$ ) } \\
\hline \multirow{2}{*}{ Non-irradiation } & Riviera & $4.22 \mathrm{ab}$ & $3.40 \mathrm{abc}$ & $2.55 \mathrm{cdef}$ & $2.05 \mathrm{defg}$ \\
\hline & Burren & $3.11 \mathrm{bcd}$ & $4.19 \mathrm{ab}$ & $3.06 \mathrm{bcd}$ & $2.88 \mathrm{cde}$ \\
\hline \multirow[t]{2}{*}{ Irradiation } & Riviera & $4.35 \mathrm{a}$ & 2.71cde & $1.38 \mathrm{fg}$ & $1.144 \mathrm{~g}$ \\
\hline & Burren & $2.68 \mathrm{cde}$ & $1.84 \mathrm{defg}$ & $1.63 \mathrm{efg}$ & $1.65 \mathrm{efg}$ \\
\hline \multicolumn{6}{|c|}{ Relative water content $(\%)$} \\
\hline \multirow[t]{2}{*}{ Irradiation } & Riviera & 90.66ab & $91.47 \mathrm{a}$ & $90.80 \mathrm{a}$ & $88.09 \mathrm{cde}$ \\
\hline & Burren & $90.10 \mathrm{abc}$ & $90.29 \mathrm{abc}$ & $90.21 \mathrm{abc}$ & $90.38 \mathrm{abc}$ \\
\hline \multirow[t]{2}{*}{ Non-irradiation } & Riviera & $90.35 \mathrm{abc}$ & 89.48abcd & $87.03 \mathrm{ef}$ & $83.80 \mathrm{~g}$ \\
\hline & Burren & $89.89 \mathrm{abc}$ & $88.18 \mathrm{bcde}$ & $87.29 \mathrm{def}$ & $85.60 \mathrm{fg}$ \\
\hline
\end{tabular}

Means followed by the same letters are not significantly different $(\mathrm{P}<0.05)$ according to Duncan's test.

The results in Table 3 showed that $\mathrm{Na}+$ increased significantly with increasing salinity in both irradiated and non irradiated treatments. Riviera and Burren genotype accumlated higher $\mathrm{Na}+$ at salt levels 10 and 12 compared with 6 and $8 \mathrm{dS} \mathrm{m}^{-1}$ in irradiated treatments reached 40.00, 43.75 and $35.00,45.00 \mathrm{gm} \mathrm{gm}^{-1}$ callus dry weight respectively. There was no significant effect of irradiation on $\mathrm{Cl}^{-}$accumulation at some salt levels in both genotypes (Table 3).

On the other hand, there was a significant difference between two genotypes at salt levels 8,10 and $12 \mathrm{dS} \mathrm{m}^{-1}$ in non irradiation treatment and at 10 and $12 \mathrm{dS} \mathrm{m}^{-1}$ in the irradiation treatment, Also showed that Burren accumlated $\mathrm{Cl}^{-}$higher than Riviera genotype at $12 \mathrm{dS}$ $\mathrm{m}^{-1}$ in both non and irradiated treatments $(63.00$ and 60.00 respectively).

The result presented in Table 4 shows that in both genotypes tissue irradiation significant decrease $\mathrm{K}+$ accumulation at salt levels $8,10,12 \mathrm{dS} \mathrm{m}^{-1}$ compared with non irradiated treatment $(5.20,15.10,11.10 \mathrm{gm}$ $\mathrm{gm}^{-1}$ callus dry weight and $5.20,3.05,4.60 \mathrm{gm} \mathrm{gm}^{-1}$ callus dry weight for Riviera and Burren respectively). It appears from the results in Table 4 that there was no significant difference in $\mathrm{Ca}++$ accumulation at all salt levels in both genotypes in non irradiation except at level $8 \mathrm{dS} \mathrm{m}^{-1}$. In irradiation treatment, Ca++ accumulation significantly decreased at salt levels 8 and

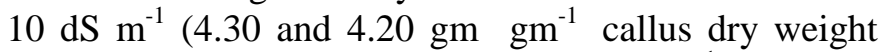
respectively) compared with 6 and $12 \mathrm{dS} \mathrm{m}^{-1}$ (6.50 and $7.35 \mathrm{mg} \mathrm{gm} \mathrm{gm}^{-1}$ callus dry weight respectively) in Riviera genotype while, in Burren genotype significantly reduced $\mathrm{Ca}++$ at $12 \mathrm{dS} \mathrm{m}^{-1}$ (4.60 gm gm ${ }^{-1}$ callus dry weight) compared with level $8 \mathrm{dS} \mathrm{m}^{-1}$ (6.75 gm gm callus dry weight). It seems that both genotypes significantly different in their accumulation of $\mathrm{Na}+, \mathrm{Cl}-$, $\mathrm{K}+$ and $\mathrm{Ca}++$, may be due to genotype dependent which are reflected in their ability to take and transfer ions within tissue. Salinity was significantly affected by accumulation of ions, which showed that $\mathrm{Ca}++$ was Oscillating with increasing accumulation of $\mathrm{Na}+$ and $\mathrm{Cl}-$ by increasing salt levels, which were associated with decrease in $\mathrm{K}+$, especially at $12 \mathrm{dS} \mathrm{m}{ }^{-1}$. This may be explained by the cells in the callus tissue are working to allow these ions to enter to increase osmotic pressure causing accumulation of ions in cytoplasm and vacuole as a result of salt stress. These results were agreed with Munns (1993), AL-Dahimawi (2009) and Shojaie (2010). While irradiation significantly affected by increasing $\mathrm{Na}+$ with decreasing $\mathrm{K}+$ this may be related to affect on mechanism of ion absorption by damage to the cellular membranes and thus affect membrane permeability or ion transport system. These results were consistent with the results of Paschinger and Vanicek (1974) and Mulawee (1980). 
Table 3. Effect of radiation and salt levels on sodium $\mathrm{Na}+$ and chloride $\mathrm{Cl}$ - ions ( $\mathrm{gm} \mathrm{gm}^{-1}$ callus dry weight) for two genotypes (Riviera and Burren) after 30 days.

\begin{tabular}{|c|c|c|c|c|c|}
\hline \multirow{2}{*}{ Radiation } & \multirow{2}{*}{ Genotypes } & \multicolumn{4}{|c|}{ Salt levels dS $\mathrm{m}^{-1}$} \\
\hline & & 6 & 8 & 10 & 12 \\
\hline \multicolumn{6}{|c|}{$\mathrm{Na}+\left(\mathrm{gm} \mathrm{gm}^{-1}\right.$ callus dry weight $)$} \\
\hline \multirow[t]{2}{*}{ irradiation Non } & Riviera & 15.32ef & $21.53 \mathrm{de}$ & $26.35 d$ & $25.27 \mathrm{~d}$ \\
\hline & Burren & $12.91 \mathrm{f}$ & $25.15 \mathrm{~d}$ & $24.88 \mathrm{~d}$ & $25.08 \mathrm{~d}$ \\
\hline \multirow[t]{2}{*}{ Irradiation } & Riviera & $22.50 \mathrm{de}$ & $26.25 \mathrm{~cd}$ & $40.00 \mathrm{ab}$ & $43.75 \mathrm{a}$ \\
\hline & Burren & $13.65 f$ & $33.75 b c$ & $35.00 \mathrm{~b}$ & $45.00 \mathrm{a}$ \\
\hline \multicolumn{6}{|c|}{$\mathrm{Cl}$ - (gm $\mathrm{gm}^{-1}$ callus dry weight) } \\
\hline \multirow[t]{2}{*}{ Non-irradiation } & Riviera & $10.50 \mathrm{~g}$ & $14.90 \mathrm{efg}$ & 28.00def & $43.65 b c$ \\
\hline & Burren & $14.00 \mathrm{fg}$ & $31.50 \mathrm{~cd}$ & $52.75 \mathrm{ab}$ & $63.00 \mathrm{a}$ \\
\hline \multirow[t]{2}{*}{ Irradiation } & Riviera & $11.40 \mathrm{~g}$ & 26.40def & $29.50 \mathrm{cde}$ & $30.65 \mathrm{~cd}$ \\
\hline & Burren & $16.65 \mathrm{defg}$ & $26.25 \mathrm{def}$ & $48.90 \mathrm{ab}$ & $60.25 \mathrm{a}$ \\
\hline
\end{tabular}

The average which have the same letter not significant difference according to Duncan polynomial test at $5 \%$ level.

Table 4. Effect of radiation and salt levels on potassium $(\mathrm{K}+)$ and calcium $(\mathrm{Ca}++)$ ions $\left(\mathrm{gm} \mathrm{gm}^{-1}\right.$ callus dry weight) for two genotypes ( Riviera and Burren) after 30 days.

\begin{tabular}{|c|c|c|c|c|c|}
\hline \multirow{2}{*}{ Radiation } & \multirow{2}{*}{ Genotypes } & \multicolumn{4}{|c|}{ Salt levels dS $\mathrm{m}^{-1}$} \\
\hline & & 6 & 8 & 10 & 12 \\
\hline \multicolumn{6}{|c|}{$\mathrm{K}+\left(\mathrm{gm}_{\mathbf{g m}^{-1}}\right.$ callus dry weight $)$} \\
\hline \multirow[t]{2}{*}{ Non-irradiation } & Riviera & $21.20 \mathrm{~b}$ & $27.97 \mathrm{a}$ & $21.73 b$ & $10.61 \mathrm{cdefg}$ \\
\hline & Burren & $14.16 \mathrm{~cd}$ & $12.02 \mathrm{cde}$ & $10.88 \mathrm{cdefg}$ & 7.66efgh \\
\hline \multirow[t]{2}{*}{ Irradiation } & Riviera & 8.40defgh & $5.20 \mathrm{fgh}$ & $15.10 \mathrm{c}$ & $11.10 \mathrm{cdef}$ \\
\hline & Burren & $5.45 \mathrm{fgh}$ & $5.20 \mathrm{fgh}$ & $3.05 \mathrm{~h}$ & $4.60 \mathrm{~h}$ \\
\hline \multicolumn{6}{|c|}{$\mathrm{Ca}++\left(\mathrm{gm} \mathrm{gm}^{-1}\right.$ callus dry weight $)$} \\
\hline \multirow[t]{2}{*}{ Non-irradiation } & Riviera & 5.69abcdef & $4.37 \mathrm{def}$ & $3.69 \mathrm{f}$ & 6.07abcde \\
\hline & Burren & $6.60 \mathrm{abc}$ & $6.90 \mathrm{a}$ & $5.93 \mathrm{bcdef}$ & 6.32abcd \\
\hline \multirow[t]{2}{*}{ Irradiation } & Riviera & $6.50 \mathrm{abc}$ & 4.30def & $4.20 \mathrm{ef}$ & $7.35 \mathrm{a}$ \\
\hline & Burren & $6.05 \mathrm{abcde}$ & $6.75 \mathrm{ab}$ & $4.70 \mathrm{bcdef}$ & $4.60 \mathrm{cdef}$ \\
\hline
\end{tabular}

The average which have the same letter not significant difference according to Duncan polynomial test at $5 \%$ level.

Data related to Proline accumulation is given in Table 5. Results showed that irradiation led to reduction in Proline accumulation in Riviera genotype at salt levels 8 and 10 $\mathrm{dS} \mathrm{m}{ }^{-1}$, whereas otherwise in salt levels 6 and $12 \mathrm{dS} \mathrm{m}^{-1}$, While in Burren genotype noted that irradiation increased proline accumulation at all salt levels compared with non irradiation. Many authors mentioned that the important of Proline in salt tolerance as a role in a protective agent for enzymes (Solomon et al., 1994) and cell organelles in cytoplasm (Van Rensburg et al., 1993). As well as, considered a carbon-nitrogen and free-radical compound of free radicals scavenger (Chinnusamy et al., 2005). Increased accumulation of proline in cells is a common response in plants under salt stress (Szabados and Savouré, 2010; AL-Shammari, 2001 and AL-Tikriti, 2002) as a results of its high rates of manufacture and low oxidation (Kumar et al., 2003). Results in Table 5 showed that significant decrease in carbohydrate accumulation in callus of Burren genotype at salt level $8 \mathrm{dS} \mathrm{m}^{-1}(2.14 \mathrm{mg}$ glucose $\mathrm{g}^{-1}$ callus fresh weight) compared with $6 \mathrm{dS} \mathrm{\textrm {m } ^ { - 1 }}$ (4.19 $\mathrm{mg}$ glucose $\mathrm{g}^{-1}$ callus fresh weight) in non irradiated treatment. On the other hand, irradiation had no significant effect on carbohydrates accumulation in both genotypes at all salt levels exception of salt level $6 \mathrm{dS} \mathrm{m}^{-1}$ in Burren genotype where carbohydrate decreased (4.19 and 1.92 $\mathrm{mg}$ glucose $\mathrm{g}^{-1}$ callus fresh weight in non- irradiated and irradiated treatment respectively).

The decrease in the carbohydrate content under some salt levels was consistent with results of AL-Shammari (2001), which found a significant decrease in carbohydrates in callus of some varieties of sugarcane reached $16-47 \%$ as compared with control treatment, explaining that in spite of salinity caused Stimulate carbohydrate metabolism enzymes, salt stress at the same time has led the cell to release a large portion of energy, to resist ionic disturbance within the cell, or may be due to transform of carbohydrates to starch by increasing salt stress (Stavarek and Rains, 1985; Omar et al., 1993). The negative effect of radiation on carbohydrates accumulation in some salt levels was agreed with results of Kebeish et al. (2015). 
Table 5. Effect of radiation and salt levels on carbohydrate and proline ( $\mathrm{gm} \mathrm{gm}^{-1}$ callus dry weight) for two genotypes (Riviera and Burren) after 30 days.

\begin{tabular}{|c|c|c|c|c|c|}
\hline \multirow{2}{*}{ Radiation } & \multirow{2}{*}{ Genotypes } & \multicolumn{4}{|c|}{ Salt levels dS $\mathrm{m}^{-1}$} \\
\hline & & 6 & 8 & 10 & 12 \\
\hline \multicolumn{6}{|c|}{ Carbohydrate (mg glucose gm $^{-1}$ callus fresh weight) } \\
\hline \multirow[t]{2}{*}{ Non-irradiation } & Riviera & $2.86 a b$ & $2.59 \mathrm{ab}$ & $2.64 \mathrm{ab}$ & $2.99 \mathrm{ab}$ \\
\hline & Burren & $4.19 \mathrm{a}$ & $2.14 \mathrm{~b}$ & $3.13 \mathrm{ab}$ & $2.30 \mathrm{~b}$ \\
\hline \multirow[t]{2}{*}{ Irradiation } & Riviera & $2.34 b$ & $2.99 \mathrm{ab}$ & $3.29 \mathrm{ab}$ & $2.06 \mathrm{~b}$ \\
\hline & Burren & $1.92 b$ & $3.20 \mathrm{ab}$ & $2.99 \mathrm{ab}$ & $3.27 \mathrm{ab}$ \\
\hline \multicolumn{6}{|c|}{ Proline micromole proline gm $^{-1}$ callus dry weight } \\
\hline \multirow[t]{2}{*}{ Non-irradiation } & Riviera & $10.89 \mathrm{cde}$ & $37.65 a$ & $23.55 b c$ & $6.20 \mathrm{e}$ \\
\hline & Burren & 8.89de & $12.95 \mathrm{cde}$ & $6.66 \mathrm{e}$ & $11.47 \mathrm{cde}$ \\
\hline \multirow[t]{2}{*}{ Irradiation } & Riviera & $16.63 \mathrm{cde}$ & $14.13 \mathrm{cde}$ & $12.48 \mathrm{cde}$ & $23.90 \mathrm{abc}$ \\
\hline & Burren & $22.24 \mathrm{bcd}$ & $30.53 \mathrm{ab}$ & 18.94 bcde & $13.29 \mathrm{cde}$ \\
\hline
\end{tabular}

The average which have the same letter not significant difference according to Duncan polynomial test at $5 \%$ level.

\section{Conflict of interest statement}

Authors declare that they have no conflict of interest.

\section{References}

Aldemita, R., Zapata, F., 1991. Anther culture of rice: effects of radiation and media components on callus induction and plant regeneration. Cereal Res. Commun. 19, 9-32.

AL-Dheimawi, A. J. M., 2009. In vitro evaluation of three grape (Vitis vinifera L.) cultivars for $\mathrm{NaCl}$ tolerance. MS Thesis. Faculty of Agriculture, University of Kufa.

AL-Moulawi, I. M. J., 1980. Effect of gamma rays (ionizing radiation) on tolerate of wheat, barley and safflower for salinity. MS Thesis. College of Science, Baghdad University.

AL-Sabri, H..A. 1988. Effect of salinity and radiation on some cellular components and water relations of in callus Four varieties of wheat Triticum spp in vitro cultured. MS Thesis. Faculty of Education. Baghdad University.

Al-Safadi, B.; Ayyoubi, Z. and Jawdat, D. 2000. The effect of gamma irradiation on potato microtuber production in vitro. Plant Cell Tiss Organ Cult., 61(3):183-187.

AL-Salhi, A. A. M. 2002. Radiosensitivity of Potatoes (Solanum tuberosum L.) Propagated In vitro to Gamma Radiation. PhD thesis. faculty of Agriculture. Baghdad University. Iraq.

AL- Shimary, I. 2001. Response of three sugarcane varieties (Sacchrum officinarum L.) callus and evaluation to salt stress. MS Thesis. Colleg of Agriculture. Baghdad University.
AL-Takriti, Sh. A. Y. 2002. Evaluation and Regeneration of salt tolerant rice plants using different techniques. $\mathrm{PhD}$ thesis. Faculty of Agriculture, Baghdad University, Iraq.

Chinnusamy, V., Jagendorf, A., Zhu, J., 2005. Understanding and improving salt tolerance in plants. Crop Sci. 45, 437-448.

Cushman, J.C., DeRocher, E.J., Bohnert, H. J., 1990. Gene expression during adaptation to salt stress. In: Environmental Injury to Plant (Ed.: Katterman, F.). Academic Press Inc., San Diego. pp.173-203.

FAO/IAEA, 1977. Manual on Mutation Breeding. IAEA, Vienna.

Forooghian, S., Esfarayeni, S., 2013. An evaluation of effect of salt stress on callus induction in different potato cultivars. Amer. Eur. J. Agric. Environ. Sci. 13(8), 1135-1140.

Hassan, S., Javed, A., 1991. In vitro radiosensitivity and rapid propagation of potato through axillary bud culture. Sarhad J. Agric. 7(4), 495-499.

Ibrahim, A. F., AL-Sadawi, A. SH., AL-Janabi, Kh. Kh., 1990. Applications of Nuclear Techniques in Plant Studies. Publications of the Iraqi Atomic Energy Organization.

Kebeish, R., Deef, H., El-Bialy, N., 2015. Effects of gamma radiation on growth, oxidative stress, antioxidant system, and alliin producing gene transcripts in Allium sativum. Int. J. Res. Stud. Biosci. 3, 161-174.

Kovacs, E., Keresztes, A., 2002. Effect of gamma and UV-B/C radiation on plant cells. Micron. 33, 199210.

Lutts, S., Kinet, J., Bouharmont, J., 1998. NaCl impact on somaclonal variation exhibited by tissue culture derived fertile plants of rice (Oryza sativa L.). J. 
Plant Physiol. 152, 92-103.

Maas, E. V., Hoffman, G. J., 1977. Crop salt tolerancecurrent assessment. J. Irrig. Drainage Divis. 103, 115-134.

Munns, R., 1993. Physiological processes limiting plant growth in saline soils: some dogmas and hypotheses. Plant Cell Environ. 16, 15-24.

Murashige, T., Skoog, T., 1962. A revised medium for rapid growth and bioassays with tobacco tissue cultures. Physiol. Plant. 15, 473-479.

Omar, M., Yousif, D., AL-Jibouri, A., AL- Rawi, M., Hameed, M., 1993. Effects of gamma rays and sodium chloride on growth and cellular constituents of sunflower (Helianthus annuus L.) callus cultures. J. Islamic Acad. Sci. 6, 69-72.

Paschinger, H., Vanicek, T., 1974. Effects of gamma irradiation on the two mechanisms of $\mathrm{Rb}(\mathrm{K})$ uptake by Cholorella. Rad. Bot. 14, 301-307.

Queiros, F., Fidalgo, F., Santos, I., Salema, R., 2007. In vitro selection of salt tolerant cell lines in Solanum tuberosum L. Biol. Plant. 51, 728-734.

Shojaie, B., Ehsanpour, A., Abdi, M., 2010. Proline, sodium and potassium concentration changes in gamma rays and $\mathrm{NaCl}$ treated potato calli. J. Cell Mol. Res. 2, 74-80.
Sonnino, A., Ancora, G., Locardi, C., 1986. In vitro mutation breeding of potato. Use of propagation by microcuttings. Symposium on Nuclear Techniques and In Vitro Culture for Plant Improvement. IAEA, Vienna. pp.385-394.

Stavarek, S., Rains, D., 1985. Effect of salinity on growth on maintenance cost of plant cells. In: Proceedings of Cellular Molecular Biology of Plant Stress (Alan, R.). pp.129-143.

Szabados, L., Savouré, A., 2010. Proline: A multifunctional amino acid. Trends Plant Sci. 15(2), 89-97.

van Harten, A.M., 1998. Mutation Breeding: Theory and Practical Applications. Cambridge University Press.

Van Rensburg, L., Krüger, G., Krüger, H., 1993. Proline accumulation as drought-tolerance selection criterion: Its relationship to membrane integrity and choroplast ultrastructure in Nicotiana tabacum L. J. Plant Physiol. 141, 188-194.

Yaycili, O., Alikamanoglu, S., 2012. Induction of salttolerant potato (Solanum tuberosum L.) mutants with gamma irradiation and characterization of genetic variations via RAPD-PCR analysis. Turk. J. Biol. 36, 405-412.

\section{How to cite this article:}

AL-Hussaini, Z. A., Yousif, SH. A., AL-Ajeely, S. A., 2017. In vitro radiosensitivity for two genotypes of potato (Solanum tuberosum L.) and physiological studies under salinity. Int. J. Curr. Res. Biosci. Plant Biol. 4(9), 7-14. doi: $\underline{\text { https://doi.org/10.20546/ijcrbp.2017.409.002 }}$ 